Плодоводство и виноградарство Юга России № 63(3), 2020 г.

УДК 634.85(470.61)

UDC 634.85(470.61)

DOI 10.30679/2219-5335-2020-3-63-30-44

DOI 10.30679/2219-5335-2020-3-63-30-44

ДОНСКИЕ АВТОХТОННЫЕ СОРТА ВИНОГРАДА ДЛЯ РАСШИРЕНИЯ СОРТИМЕНТА ВИНОГРАДНЫХ НАСАЖДЕНИЙ В НИЖНЕМ ПРИДОНЬЕ

Ганич Валентина Алексеевна канд. с.-х. наук ведущий научный сотрудник лаборатории ампелографии e-mail: ganich1970@yandex.ru

Наумова Людмила Георгиевна канд. с.-х. наук ведущий научный сотрудник лаборатории ампелографии e-mail: LGnaumova@yandex.ru

Матвеева Наталья Викторовна старший научный сотрудник лаборатории технологии виноделия e-mail: n-matveeva78@mail.ru

Всероссийский научно-исследовательский институт виноградарства и виноделия имени Я.И. Потапенко филиал Федерального государственного бюджетного научного учреждения «Федеральный Ростовский Аграрный научный центр», Новочеркасск, Россия

Цель исследований - всестороннее изучение группы донских автохтонных сортов винограда для обоснования целесообразности введения их в сортимент виноградных насаждений Ростовской области для производства вин защищенных наименований места происхождения. Исследования проводились в 2015-2019 гг. на Донской ампелографической коллекции имени Я.И. Потапенко (Новочеркасск). Объект исследований - автохтонные донские сорта винограда: Белобуланый, Кумшацкий белый, Шампанчик цимлянский, Шампанчик-2, Сыпун черный, Старый горюн и Бессергеневский № 5; контроль

\section{DON AUTOCHTHONOUS GRAPEVINE VARIETIES FOR EXPANDING THE ASSORTMENT OF VINEYARDS IN THE LOWER DON REGION}

Ganich Valentina Alekseyevna Cand. Agr. Sci.

Leading Research Associate of Ampelographic Laboratory e-mail: ganich1970@yandex.ru

Naumova Lyudmila Georgievna Cand. Agr. Sci.

Leading Research Associate of Ampelographic Laboratory e-mail: LGnaumova@yandex.ru

Matveyeva Natalia Viktorovna Senior Research Associate of Winemaking Laboratory e-mail: n-matveeva78@mail.ru

\section{All-Russian Research Institute named after Ya.I. Potapenko for Viticulture and Winemaking - Branch of Federal State Budget scientific Institution «Federal Rostov Agricultural Research Center», Novocherkassk, Russia}

The purpose of the research was to study comprehensively the group of Don autochthonous grapevine varieties with a view to justify the feasibility of introducing them into the assortment of vineyards in the Rostov Region for the production of wines of protected appellation of origin districts.

The research was conducted in 2015-2019 at the Potapenko Don ampelographic collection (Novocherkassk). The object of the research were autochthonous Don grapevine varieties: Belobulaniy, Kumshatskiy Beliy, Champanchik Tsimlyanskiy, Champanchik-2, 
для белых сортов - Сибирьковый, для красных - Красностоп золотовский. Сорта изучались в привитой культуре на подвое Кобер 5ББ. Схема посадки кустов 3,0 х 1,5 м. Культура неполивная, укрывная. Наибольшая средняя масса грозди была у сорта Кумшацкий белый 408 г. Очень высокая расчетная урожайность (17 т/га и более) - у сортов Белобуланый и Кумшацкий белый.

Очень высокая сахаристость сока ягод (более 23 г/100 $\mathrm{cm}^{3}$ ) - у сортов Шампанчик цимлянский и Красностоп золотовский.

Высокие дегустационные оценки получили столовые сухие вина из сортов Кумшацкий белый, Белобуланый (на уровне контрольного сорта Сибирьковый - 8,8 балла) и сорт Сыпун черный ( 8,8 балла), у контрольного сорта Красностоп золотовский - 8,9 балла. По результатам проведенных исследований, можно сделать вывод, что по совокупности положительных хозяйственно-ценных признаков и качеству винодельческой продукции белые технические сорта винограда Кумшацкий белый, Белобуланый и красный технический сорт Сыпун черный являются перспективными сортами для введения их в сортимент виноградных насаждений Нижнего Придонья, что позволит расширить ассортимент высококачественных вин защищенных наименований места происхождения.

Ключевые слова: ВИНОГРАД, ABTOХTOHНЫЕ COPTA, АМПЕЛОГРАФИЧЕСКАЯ КОЛЛЕКЦИЯ, УРОЖАЙНОСТЬ, ТЕХНОЛОГИЧЕСКАЯ ОЦЕНКА ВИН, ОРГАНОЛЕПТИЧЕСКАЯ ХАРАКТЕРИСТИКА ВИНА
Sypun Cherniy, Stariy Goryun and Bessergenevsky No. 5; Sibirkoviy was a control for white varieties, Krasnostop Zolotovsky - for red ones. Varieties were studied in grafted culture on Cober 5BB rootstock. Covered grapevine culture was used without watering. The planting scheme was $3.0 \times 1.5 \mathrm{~m}$. Kumshatsky Beliy had the highest average mass of a bunch $408 \mathrm{~g}$. The varieties of Belobulaniy and Kumshatskiy Beliy had a very high estimated yield (17 t/ha or more).

The varieties of Champanchik Tsimlyanskiy and Krasnostop Zolotovskiy had a very high sugar content of berry juice (more than $23 \mathrm{~g} / 100 \mathrm{~cm}^{3}$ ). High degustation evaluations were given to table dry wines from the varieties of Kumshatskiy Beliy, Belobulaniy (at the level of the control grade Sibirkoviy 8.8 points), and the Sipun Cherniy variety (8.8 points), the control Krasnostop Zolotovsky variety had 8.9 points. Based on the results of the study we conclude that the total positive agronomic traits and the quality of wine production of white technical grapevines of Kumshatskiy Beliy, Belobulanniy, and red technical Sipun Cherniy variety are promising varieties for introducing to the assortment of vineyards of the Lower Don area, to expand the range of quality wines of protected appellations of origin.

Key words: GRAPEVINE,

AUTOCHTHONOUS

GRAPEVINEVARIETIES, AMPELOGRAPHIC COLLECTION, YIELD CAPACITY, TECHNOLOGICAL EVALUATION OF WINES, ORGANOLEPTIC CHARACTERISTICS OF WINE

Введение. Сохранение и изучение растительного биоразнообразия, выявление новых и оценка запасов используемых видов приобретает теоретическую, научную и практическую значимость, и актуально в настоящее время. Мировое сообщество в ближайшей перспективе отдает приори- 
тет сохранению растений в различных условиях произрастания. Мобилизация сортовых ресурсов винограда в ампелографических коллекциях играет важную роль в сохранении и использовании генофонда винограда, так как существует реальная угроза потери значительного числа сортов в связи с исчезновением во многих регионах мира дикорастущего винограда, уменьшением количества сортов, реконструкцией старых насаждений и т.д. Большинство аборигенных и малораспространенных сортов в настоящее время сохранилось только благодаря коллекциям.

Во всем мире (США, Германия, Франция, Китай, Индия, Испания, Италия, Словакия, Россия и др.) изучению, сохранению и приумножению генетического потенциала культурных растений уделяется особое внимание [1-11]. Во многих странах главной задачей сбора и сохранения генофонда рода Vitis является сохранение местных (аборигенных, автохтонных) сортов винограда, которые являются исключительно частью природного наследия данной местности и не произрастают в других винных регионах [12-16].

Не все автохтонные донские сорта винограда равноценны по качеству продукции, но в настоящее время трудно представить лучшие вина России без высококачественных донских белых вин из урожая сортов Сибирьковый, Кумшацкий, Пухляковский и особенно без известных всему миру красных вин высочайшего качества из сортов Красностоп золотовский и Цимлянский чёрный [17].

Незаслуженно приниженный авторитет автохтонных сортов винограда нашего отечества заметно сказывается на их распространении. Автохтоны - нераскрытый пласт знаний о потенциальных возможностях промышленного производства и использования в комбинативной и клоновой селекции [18]. Именно в генотипах автохтонных сортов винограда могут быть выявлены комплексы признаков, обеспечивающие адаптивность растений к конкретным агроклиматическим условиям возделывания [19]. 
В последнее десятилетие в мире наиболее актуальным стало изучение автохтонных сортов винограда [11-17, 19-23]. Продолжение изучения этих сортов позволит выделить из числа малораспространенных и редких новые образцы с высокими технологическими свойствами для качественного виноделия.

Изучение автохтонных донских сортов винограда на коллекции в Новочеркасске ведется с 1936 года. Ведущими сортами в насаждениях Ростовской области были автохтонные и интродуцированные сорта, издавна культивируемые на Дону, о чём свидетельствуют данные переписи 1953 года. В те годы автохтонные и издавна распространенные на Дону сорта винограда занимали около 60 \% насаждений [17].

В Государственном реестре сортов винограда, допущенных к использованию в Российской Федерации, с 1959 года по настоящее время находятся шесть автохтонных донских сортов винограда - Варюшкин, Красностоп золотовский, Плечистик, Пухляковский, Сибирьковый, Цимлянский черный.

Важными направлениями улучшения и расширения сырьевой базы виноделия, увеличения выпуска высококачественной продукции является введение в сортимент таких технических сортов винограда, которые обладают высокой урожайностью и качеством продукции на уровне контрольных сортов. Виноградное вино, как никакой другой продукт из растительного сырья, зависит от места происхождения и условий выращивания. С использованием автохтонных сортов винограда связана возможность производства высококачественных и уникальных донских вин защищенных наименований места происхождения (ЗНМП).

Цель исследований - всестороннее изучение группы донских автохтонных сортов винограда для обоснования целесообразности введения их в сортимент виноградных насаждений Ростовской области для производства вин ЗНМП. 
Объекты и методы исследований. Исследования проводились в 2015-2019 гг. на Донской ампелографической коллекции имени Я.И. Потапенко (ВНИИВиВ-филиал ФГБНУ ФРАНЦ, г. Новочеркасск). Объект исследований - автохтонные донские сорта винограда: Белобуланый, Кумшацкий белый, Шампанчик цимлянский, Шампанчик-2, Сыпун черный, Старый горюн и Бессергеневский № 5. В качестве контрольных сортов были взяты: для белых - Сибирьковый; для красных - Красностоп золотовский. Сорта изучались в привитой культуре на подвое Берландиери х Рипариа Кобер 5ББ. Схема посадки кустов 3,0 х 1,5 м. Культура неполивная, укрывная. Формировка кустов многорукавная веерная. Грунтовые воды залегают на глубине 15-20 м и не оказывают влияния на развитие виноградных кустов, так как недоступны для корневой системы винограда. Технология возделывания виноградников общепринятая для северной зоны промышленного виноградарства РФ.

Из всех районов виноградарства Северного Кавказа Ростовская область находится в наиболее суровых климатических условиях. Зимы неустойчивые, с суровыми морозами и частыми оттепелями. Виноградные кусты приходится укрывать на зиму, предохраняя от губительных низких температур. Средняя глубина промерзания почвы 39 см. Весной наблюдаются поздние, а осенью - ранние заморозки. По количеству осадков регион отличается недостаточным увлажнением (200-500 мм годовых осадков) при очень высокой летней инсоляции и испарении.

Температурный режим вегетационного периода винограда почти по всей области является достаточно благоприятным. Значительная длительность периода с температурами выше $10{ }^{\circ} \mathrm{C}$ говорит о том, что развитие, вызревание и достаточная сахаристость винограда обеспечиваются летними температурами. Ведению культуры винограда в этой зоне благоприятствует продолжительное солнечное освещение в начале осени - в период созревания винограда, что позволяет получить урожай высокого качества. 
Плодоводство и виноградарство Юга России № 63(3), 2020 г.

Почвы представлены обыкновенными карбонатными черноземами, среднемощными, слабо гумусированными, тяжелосуглинистыми на лессовидных суглинках. Не засолены, с высоким обеспечением усваиваемыми формами фосфора, средним обеспечением подвижным калием, обогащены карбонатами кальция. Мощность гумусового горизонта (A-B) достигает 90 см. Гумуса в плантажном слое содержится 3,5-4,0 \%.

Изучение сортов винограда проводили с использованием общепринятых в виноградарстве методик: М.А. Лазаревского, А.Г. Амирджанова, Н.Н. Простосердова [24-25]. Сахаристость сока ягод определяли по ГОСТ 27198-87, титруемую кислотность - ГОСТ 32114-2013, объемную долю этилового спирта - ГОСТ 32095-2013, летучие кислоты - ГОСТ 320012012, общий диоксид серы - ГОСТ 32115-2013, приведенный экстракт ГОСТ 32000-2012. Образцы виноматериалов готовились в лаборатории технологии виноделия по классической технологии согласно нормативной документации [26, 27], оценивались дегустационной комиссией института, утвержденной приказом директора, на закрытых научных дегустациях согласно ГОСТ 32051-2013.

Обсужжение результатов. Анализируя данные фенологических наблюдений, отмечаем, что в среднем за 5 лет исследований распускание почек в условиях Нижнего Придонья проходило в период с 26 по 28 апреля (табл. 1). Одновременное распускание почек у сортов винограда с различными сроками созревания можно объяснить тем, что независимо от срока созревания все сорта в начальной фазе вегетации обладают почти одинаковыми биологическими требованиями к условиям среды, прежде всего, к сумме активных температур воздуха [30].

Цветение проходило в сроки с 1 по 5 июня, начало цветения 1 июня отмечено у сорта Сибирьковый, 5 июня - у сортов Кумшацкий белый, Старый горюн и Бессергеневский № 5. Начало созревания ягод у всех изучаемых сортов отмечено в первой декаде августа. 
Таблица 1 - Прохождение фаз вегетации сортов винограда

\begin{tabular}{|c|c|c|c|c|c|c|}
\hline \multirow[b]{2}{*}{ Сорт } & \multicolumn{4}{|c|}{ Дата начала фенофаз } & \multicolumn{2}{|c|}{$\begin{array}{c}\text { От распускания } \\
\text { почек до полной } \\
\text { зрелости ягод }\end{array}$} \\
\hline & 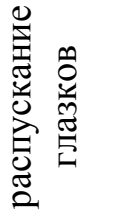 & 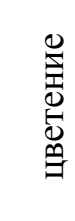 & 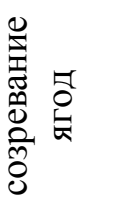 & 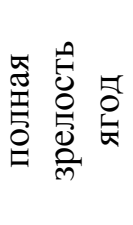 & 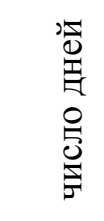 & 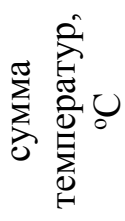 \\
\hline \multicolumn{7}{|c|}{ Ранне-среднего периода созревания (126-135 дней) } \\
\hline Сибирьковый (к) & 26.04 & 1.06 & 26.07 & 7.09 & 134 & 2986 \\
\hline \multicolumn{7}{|c|}{ Среднего периода созревания (136-145 дней) } \\
\hline Шампанчик цимлянский & 28.04 & 2.06 & 6.08 & 14.09 & 139 & 3159 \\
\hline Кумшацкий белый & 27.04 & 5.06 & 4.08 & 15.09 & 141 & 3163 \\
\hline Красностоп золотовский (к) & 27.04 & 3.06 & 30.07 & 17.09 & 143 & 3241 \\
\hline Старый горюн & 26.04 & 5.06 & 3.08 & 18.09 & 145 & 3227 \\
\hline Сыпун черный & 28.04 & 3.06 & 2.08 & 20.09 & 145 & 3267 \\
\hline \multicolumn{7}{|c|}{ Средне-позднего периода созревания (146-155 дней) } \\
\hline Белобуланый & 27.04 & 2.06 & 9.08 & 27.09 & 153 & 3351 \\
\hline Бессергеневский № 5 & 27.04 & 5.06 & 2.08 & 29.09 & 155 & 3411 \\
\hline \multicolumn{7}{|c|}{ Позднего периода созревания (156-165 дней) } \\
\hline Шампанчик-2 & 26.04 & 3.06 & 8.08 & 30.09 & 157 & 3427 \\
\hline
\end{tabular}

По количеству дней от распускания почек до полной зрелости ягод сорта распределились следующим образом: от ранне-среднего периода созревания (126-135 дней) - сорт Сибирьковый до позднего (156-165 дней) сорт Шампанчик-2.

По данным агробиологических учетов, процент распустившихся глазков у изучаемых сортов колебался от 70,0 у сорта Красностоп золотовский до 86,3 \% у сорта Сыпун черный (табл. 2). За исследуемый период процент плодоносных побегов находился в пределах от 33,5 (сорт Старый горюн) до 73,8 \% (сорт Шампанчик-2), у контрольных сортов: Красностоп золотовский $-67,4$; Сибирьковый $-66,3 \%$.

Важным показателем продуктивности является коэффициент плодоношения, величина которого носит генотипический характер. Высокий показатель коэффициента плодоношения $-1,0$ и более - отмечен у сортов Шампанчик-2 $(1,4)$, Сыпун черный и Белобуланый $(1,0)$; у контрольных сортов: Сибирьковый - 1,1; Красностоп золотовский - 0,9. 
Плодоводство и виноградарство Юга России № 63(3), 2020 г.

Таблица 2 - Хозяйственно-ценные признаки изучаемых сортов винограда

\begin{tabular}{|c|c|c|c|c|c|c|}
\hline Сорт & 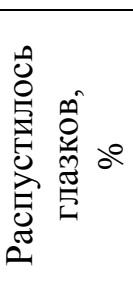 & 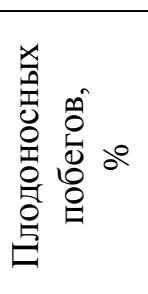 & 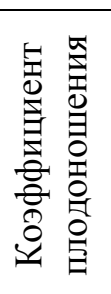 & 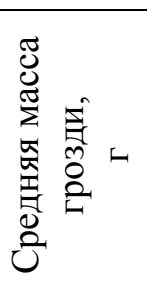 & 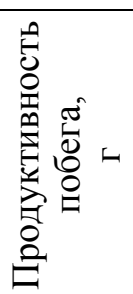 & 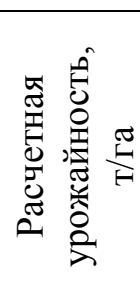 \\
\hline \multicolumn{7}{|c|}{ Урожайность очень высокая (17 т/га и более) } \\
\hline Белобуланый & 74,1 & 65,4 & 1,0 & 278 & 278 & 19,7 \\
\hline Кумшацкий белый & 71,3 & 54,5 & 0,7 & 408 & 286 & 16,9 \\
\hline \multicolumn{7}{|c|}{ Урожайность средняя (9-12 т/га) } \\
\hline Сибирьковый (к) & 70,6 & 66,3 & 1,1 & 200 & 220 & 11,3 \\
\hline Сыпун черный & 86,3 & 62,2 & 1,0 & 146 & 146 & 9,9 \\
\hline Бессергеневский № 5 & 79,8 & 55,7 & 0,7 & 233 & 163 & 9,4 \\
\hline Шампанчик-2 & 81,8 & 73,8 & 1,4 & 112 & 157 & 9,3 \\
\hline Старый горюн & 73,6 & 33,5 & 0,4 & 290 & 120 & 8,6 \\
\hline \multicolumn{7}{|c|}{ Урожайность низкая (5-8 т/га) } \\
\hline Красностоп золотовский (к) & 70,0 & 67,4 & 0,9 & 136 & 122 & 8,2 \\
\hline \multicolumn{7}{|c|}{ Урожайность очень низкая (до 4 т/га) } \\
\hline Шампанчик цимлянский & 78,4 & 49,2 & 0,6 & 115 & 69 & 3,5 \\
\hline \multicolumn{4}{|c|}{ HCP } & $\mathbf{5 3 , 5}$ & 77,9 & 6,8 \\
\hline
\end{tabular}

Средняя масса грозди была наибольшей у сорта Кумшацкий белый 408 г. Грозди массой более 200 г имели сорта Старый горюн (290 г), Белобуланый (278 г), Бессергеневский № 5 (233 г) и контрольный сорт Сибирьковый (200 г). Самые мелкие грозди у сорта Шампанчик-2 (112 г).

Продуктивность побегов напрямую зависит от коэффициента плодоношения и средней массы грозди. Наиболее высокая продуктивность побегов была у сортов: Кумшацкий белый - 286 г, Белобуланый - 278 г; у контрольных сортов: Сибирьковый - 220 г, Красностоп золотовский - 122 г.

Оценка урожайности является одной из наиболее ответственных задач сортоизучения винограда. Очень высокая расчетная урожайность (17 т/га и более) у сортов Белобуланый и Кумшацкий белый. Низкая урожайность (5-8 т/га) у сорта Красностоп золотовский, а очень низкая (до 4 т/га) у сорта Шампанчик цимлянский. Сорта Сибирьковый, Сыпун черный, Бессергеневский № 5, Шампанчик-2 и Старый горюн имели среднюю урожайность (9-12 т/га).

Созревание урожая и накопление сахаров в соке ягод винограда зависит от метеорологических условий в этот период. Как сорта- 
сахаронакопители (содержание сахаров в соке ягод более 23 г/100 см${ }^{3}$ ) выделились Шампанчик цимлянский и Красностоп золотовский. Высокая концентрация сахаров (21-23 г/100 см³) отмечена у сортов Бессергеневский № 5, Сыпун черный, Старый горюн и Сибирьковый (табл. 3). Повышенная кислотность (более 9 г/дм³) отмечена у сортов Шампанчик-2 и Шампанчик цимлянский.

Таблица 3 - Кондиции урожая сортов винограда

\begin{tabular}{|c|c|c|c|}
\hline \multirow{2}{*}{ Название сорта } & \multirow{2}{*}{$\begin{array}{c}\text { Дата } \\
\text { химического } \\
\text { анализа }\end{array}$} & \multicolumn{2}{|c|}{$\begin{array}{l}\text { Массовая концентрация } \\
\text { в соке ягод }\end{array}$} \\
\hline & & $\begin{array}{l}\text { сахаров, } \\
\Gamma / 100 \mathrm{~cm}^{3}\end{array}$ & $\begin{array}{c}\text { титруемых } \\
\text { кислот, г/дм }{ }^{3}\end{array}$ \\
\hline \multicolumn{4}{|c|}{ Очень высокая сахаристость сока ягод (более 23 г/100 см³) } \\
\hline Шампанчик цимлянский & 15.09 & 24,4 & 9,1 \\
\hline Красностоп золотовский (к) & 23.09 & 24,3 & 7,0 \\
\hline \multicolumn{4}{|c|}{ Высокая сахаристость сока ягод $\left(21-23\right.$ г/100 см $\left.{ }^{3}\right)$} \\
\hline Бессергеневский № 5 & 20.09 & 22,5 & 7,3 \\
\hline Сыпун черный & 19.09 & 22,2 & 6,4 \\
\hline Старый горюн & 20.09 & 21,5 & 7,8 \\
\hline Сибирьковый (к) & 9.09 & 21,1 & 6,2 \\
\hline \multicolumn{4}{|c|}{ Средняя сахаристость сока ягод $\left(18-20\right.$ г/100 $\left.\mathrm{cm}^{3}\right)$} \\
\hline Кумшацкий белый & 14.09 & 20,3 & 7,1 \\
\hline Шампанчик-2 & 21.09 & 19,8 & 9,3 \\
\hline Белобуланый & 27.09 & 18,8 & 6,2 \\
\hline
\end{tabular}

Кондиционное сырье является основой производства высококачественных столовых вин. Содержание сахаров и титруемых кислот в соке ягод соответствовало требованиям, предъявляемым к сырью ГОСТ $31782-$ 2012 «Виноград свежий машинной и ручной уборки для промышленной переработки».

Содержание сахаров в винограде было оптимальным для получения вин с содержанием спирта 10,9-13,6 \% (табл. 4). Титруемая кислотность виноматериалов была на уровне 5,5-7,8 г/дм³ и обеспечила микробиологическую стойкость, что способствовало получению качественных столовых вин. Летучая кислотность находилась в пределах 0,36-0,72 г/дм³ и не превышала нормативов, допускаемых ГОСТ (не выше 1,1 г/дм³). Содержание сахаров составило 1,2-2,8 г/дм³ ГОСТ (не выше 4 г/дм³). 
Таблица 4 - Химические показатели виноматериалов

\begin{tabular}{|c|c|c|c|c|c|c|}
\hline \multirow[b]{2}{*}{ Виноматериал из сорта } & \multirow[b]{2}{*}{ 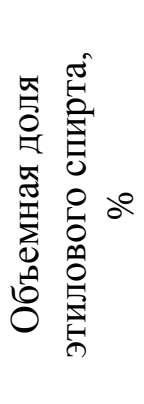 } & \multicolumn{5}{|c|}{ Массовая концентрация } \\
\hline & & 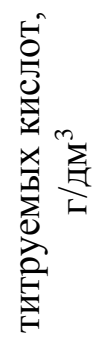 & 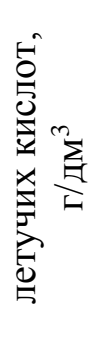 & 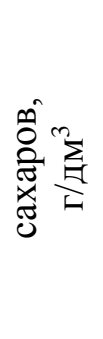 & 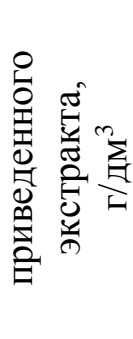 & 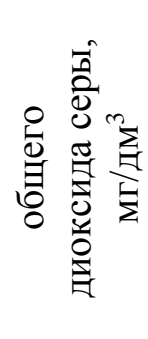 \\
\hline Белобуланый & 10,9 & 6,0 & 0,36 & 1,2 & 20,2 & 67,8 \\
\hline Бессергеневский № 5 & 12,9 & 6,5 & 0,48 & 1,6 & 23,5 & 89,2 \\
\hline Красностоп золотовский (к) & 13,2 & 5,5 & 0,68 & 2,0 & 26,5 & 91,2 \\
\hline Кумшацкий белый & 11,2 & 6,7 & 0,44 & 2,8 & 21,5 & 46,8 \\
\hline Сибирьковый (к) & 11,8 & 5,6 & 0,48 & 1,7 & 20,1 & 85,1 \\
\hline Старый горюн & 12,2 & 6,5 & 0,68 & 2,2 & 22,6 & 102,4 \\
\hline Сыпун черный & 12,5 & 6,0 & 0,72 & 1,5 & 23,4 & 76,2 \\
\hline Шампанчик-2 & 11,0 & 7,8 & 0,44 & 2,2 & 22,4 & 92,5 \\
\hline Шампанчик цимлянский & 13,6 & 6,7 & 0,38 & 2,5 & 23,1 & 102,6 \\
\hline
\end{tabular}

Одним из основных показателей качества готового вина является приведенный экстракт, позволяющий судить о натуральности, типичности, полноте вкуса, он дает объективную оценку выдержанным винам, готовой винодельческой продукции. Содержание экстракта зависит от сорта винограда, условий выращивания, степени зрелости ягод, способа их переработки и типа вина. У исследуемых сортов приведенный экстракт был на уровне 20,1-26,5 г/дм³ при минимально допустимом в винах географических наименований 17 г/дм³ для белых вин, и 19 г/дм³ для красных. Содержание общего диоксида серы находилось в пределах от 46,8 до 102,6 мг/дм ${ }^{3}$, что соответствовало требованиям технологической инструкции (не более 200 мг/дм³ ) для сухих вин.

Критерием качества для сортов технического направления использования является органолептическая оценка вина. Дегустационная оценка зависит от оригинальности и гармоничности ароматического комплекса. Высокие дегустационные оценки на уровне контрольного сорта Сибирьковый (8,8 балла) получили белые сухие столовые вина из сортов Кумшацкий белый, Белобуланый (8,8 балла) и Шампанчик цимлянский (8,7 балла) (табл. 5). 


\section{Таблица 5 - Органолептическая характеристика и дегустационные оценки вин}

\begin{tabular}{|c|c|c|}
\hline Сорт & Органолептическая характеристика вина & 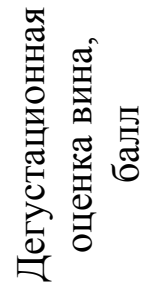 \\
\hline \multicolumn{3}{|c|}{ Белые сухие столовые вина } \\
\hline Сибирьковый (к) & $\begin{array}{l}\text { Бледно-соломенного цвета, с зеленоватым оттенком. } \\
\text { Аромат яркий, типичный, с оттенками полевых трав } \\
\text { и цветов. Вкус полный, мягкий, гармоничный. В по- } \\
\text { слевкусии легкие цветочно-медовые нотки. }\end{array}$ & 8,8 \\
\hline Кумшацкий белый & $\begin{array}{l}\text { Бледно-соломенного цвета, с зеленоватым оттенком. } \\
\text { Богатый аромат с нежными нотками полевых трав и } \\
\text { цветов, переходящими во вкус. Вкус полный, сла- } \\
\text { женный, гармоничный, приятное послевкусие. }\end{array}$ & 8,8 \\
\hline Белобуланый & $\begin{array}{l}\text { Бледно-соломенного цвета, с зеленоватым оттенком. } \\
\text { Обладает ярким ароматом полевых трав и цветов. } \\
\text { Вкус мягкий, округлый, долгое, богатое послевкусие. }\end{array}$ & 8,8 \\
\hline $\begin{array}{l}\text { Шампанчик } \\
\text { цимлянский }\end{array}$ & $\begin{array}{l}\text { Бледно-соломенного цвета. Яркий, сортовой аромат, } \\
\text { с легкими тонами полевых трав. Вкус насыщенный, } \\
\text { полный, гармоничный. }\end{array}$ & 8,7 \\
\hline Шампанчик-2 & $\begin{array}{l}\text { Бледно-соломенного цвета с легким зеленоватым } \\
\text { оттенком. В аромате нежные тона луговых трав и } \\
\text { цветов, переходящие во вкус. Вкус полный, умеренно } \\
\text { свежий. }\end{array}$ & 8,6 \\
\hline \multicolumn{3}{|c|}{ Красные сухие столовые вина } \\
\hline $\begin{array}{l}\text { Красностоп } \\
\text { золотовский (к) }\end{array}$ & $\begin{array}{l}\text { Насыщенного темно-рубинового цвета. Сложный } \\
\text { аромат с тонами смородины и вишни. Вкус полный, } \\
\text { танинный, экстрактивный, богатое послевкусие. }\end{array}$ & 8,9 \\
\hline Сыпун черный & $\begin{array}{l}\text { Рубинового цвета с гранатовым оттенком. В аромате } \\
\text { тона смородины и вишни. Вкус слаженный бархати- } \\
\text { стый, с долгим, богатым послевкусием. }\end{array}$ & 8,8 \\
\hline Старый горюн & $\begin{array}{l}\text { Темно-рубинового цвета. Аромат легкий, с ягодно- } \\
\text { терновыми оттенками. Вкус полный с гармоничным } \\
\text { послевкусием и хорошим балансом между спиртом и } \\
\text { кислотностью. }\end{array}$ & 8,6 \\
\hline $\begin{array}{l}\text { Бессергеневский } \\
\text { № } 5\end{array}$ & $\begin{array}{l}\text { Темно-рубинового цвета. Аромат сложный, с оттен- } \\
\text { ками черной смородины, переходящий во вкус. Вкус } \\
\text { гармоничный, умеренная кислотность, приятное по- } \\
\text { слевкусие. }\end{array}$ & 8,6 \\
\hline
\end{tabular}

Вина были прозрачными, имели бледно-соломенный цвет, с зеленоватым оттенком, богатую палитру сортовых ароматов с нотками полевых трав и цветов. Вкус полный, гармоничный, с долгим приятным послевкусием. 
Плодоводство и виноградарство Юга России № 63(3), 2020 г.

Среди красных образцов наиболее высокие оценки получили вина из контрольного сорта Красностоп золотовский - 8,9 балла и Сыпун черный 8,8 балла. Красные вина имели темно-рубиновый цвет, отличались нежным ароматом с различными ягодными оттенками, вкус полный, гармоничный с долгим приятным послевкусием.

Сорта, получившие дегустационные оценки на уровне 8,6 балла (Старый горюн, Бессергеневский № 5, Шампанчик-2), имеют высокий потенциал для производства столовых сухих вин высокого качества.

Bbыводы. Контрольные сорта Красностоп золотовский и Сибирьковый являются наиболее ценными автохтонными сортами Дона; вина, получаемые из этих сортов, - высочайшего качества. По результатам проведенных исследований, можно сделать заключение, что по совокупности положительных хозяйственно ценных признаков и качеству винодельческой продукции белые технические сорта винограда Кумшацкий белый, Белобуланый и красный технический сорт Сыпун черный являются перспективными сортами для введения их в сортимент виноградных насаждений Нижнего Придонья, что позволит расширить ассортимент высококачественных вин защищенных наименований места происхождения.

\section{Литература}

1. Полулях А.А., Волынкин В.А., Лиховской В.В. Генетические ресурсы винограда института «Магарач». Проблемы и перспективы сохранения // Вавиловский журнал генетики и селекции. 2017. Т. 21. № 6. C. 608-616. DOI: 10.18699/VJ17.276

2. Marrano A., Grzeskowiak L., Moreno Sanz P., Lorenzi S. et al. Genetic diversity and relationships in the grapevine germplasm collection from Central Asia // Vitis - Journal of Grapevine Research. Vol. 54 (Special Issue): January 2015: P. 233-237.

3. Alba V., Bergamini C., Genghi R. et al. Ampelometric Leaf Trait and SSR Loci Selection for a Multivariate Statistical Approach in Vitis vinifera L. Biodiversity Management // Molecular Biotechnology. 2015; 57: 709. [Электронный ресурс]. URL: https://doi.org/10.1007/s12033-015-9862-5 (дата обращения 15.06.2019)

4. Failla O. East -West collaboration for grapevine diversity exploration and mobilization of adaptive traits for breeding: A four years story // Vitis - Journal of Grapevine Research. 2015; 54: 1-4. 
5. Maletić E., Pejić I., Karoglan Kontić J. et al. Ampelographic and genetic characterization of Croatian grapevine varieties // Vitis - Journal of Grapevine Research 2015; 54 (Special Issue): 93-98.

6. Petrov V.S., Aleinikova G.Yu., Naumova L.G., Lukyanova A.A. Adaptive reaction of grape varieties in conditions of climate change // Лозарство и винарство. 2018; 6: 18-31.

7. Zoghlami N., Riahi L., Laucou V. et al. Genetic structure of endangered wild grapevine Vitis vinifera ssp. sylvestris populations from Tunisia: Implications for conservation and management // Forest Ecology and Management. 2013; 310: 896-902. DOI 10.1016/j.foreco.2013.09.039

8. Анапская ампелографическая коллекция - крупнейший центр аккумуляции и изучения генофонда винограда в России / М.И. Панкин, В.С. Петров, А.А. Лукьянов и др. // Вавиловский журнал генетики и селекции. 2018. № 1 (22). С. 54-59. DOI: $10.18699 / \mathrm{VJ} 18.331$

9. Maghradze D., Maletic E., Maul E., Faltus M., Failla O. Field genebank standards for rapevines // Vitis. 2015; 54:273-279.

10. Новикова Л.Ю., Наумова Л.Г. Структурирование ампелографической коллекции по фенотипическим характеристикам и сравнение реакции сортов винограда на изменения климата // Вавиловский журнал генетики и селекции. 2019. Т. 23 № 6. C. 142-149. DOI:10.18699/VJ19.551

11. Goryslavets S, Risovannaya V, Memetova E. et al. Genetic diversity of ancient grape cultivars of the Crimea region // Vitis - Journal of Grapevine Research. 2015; 54(1):37-41.

12. Pelengic R., Koruza B. Slovenia grapevine germplasm // Acta Agriculturae Slovenica. 2012; 99(3):429-432.

13. Li S.H., Archbold D., London J. Collection, conservation, evaluation and utilization of Vitis amurensis germplasm resources in China // Acta Horticulturae. 2015; 1082: 79-86. DOI: 10.17660/ActaHortic.2015.1082.10

14. Maul E., Töpfer R., Carka F. et al. Identification and characterization of grapevine genetic resources maintained in Eastern European Collections // Vitis. 2015; 54:5-12.

15. Характеристика некоторых аборигенных дагестанских сортов винограда методом SSR-анализа и по основным ампелографическим признакам листьев / Е.Т. Ильницкая, И.И. Супрун, Л.Г. Наумова и др. // Вавиловский журнал генетики и селекции. 2017. Т. 21. № 6. C. 617-622. DOI: 10.18699/VJ17.277.

16. Изучение генетического сходства донских аборигенных сортов винограда с применением SSR-анализа и по основным ампелографическим признакам листа / Е.Т. Ильницкая, С.В. Токмаков, И.И. Супрун и др. // Сельскохозяйственная биология. 2016. T. 51. № 1. С. 60-67. DOI: 10.15389/agrobiology.2016.1.60rus

17. Донские аборигенные сорта винограда. 2-е изд. перераб. и доп. / А.М. Алиев, Л.В. Кравченко, Л.Г. Наумова и др. Новочеркасск: Изд-во ВНИИВиВ им. Я.И. Потапенко Россельхозакадемии, 2013. 132 с.

18. Трошин Л.П. Ампелография и селекция винограда. Краснодар: Вольные мастера, 1999. $138 \mathrm{c.}$

19. Ильницкая Е.T., Токмаков С.В. Изучение полиморфизма SSR-локусов южнороссийских аборигенных сортов винограда [Электронный ресурс] // Плодоводство и виноградарство Юга России. 2014. № 27(3). С. 1-6. URL: http:// journalkubansad.ru/pdf/14/03/01.pdf. (дата обращения: 02.05.2020).

20. Панахов Т., Салимов В., Наджафов Д. Малораспространенные ценные сорта винограда Нахичевани // Виноделие и виноградарство. 2011. № 5. С.38-39.

21. Участие грузинских сортов в селекции винограда / Т. Вахтангадзе, Д. Маградзе, Р. Чипашвили и др. // Интерактивная ампелография и селекция винограда: матер. междун. симпоз. Краснодар, 2012. С. 7. 
22. Салимов В.С. Сбор, сохранение и перспективы продолжительного использования генетических ресурсов винограда // Интерактивная ампелография и селекция винограда: матер. междун. симпоз. Краснодар, 2012. С. 197-198.

23. Аджиев А.М., Мусаев И.А., Караев М.К. Аборигенные сорта винограда Дагестана как генофонд для селекции новых сортов // Мобилизация и сохранение генетических ресурсов винограда, совершенствование методов селекционного процесса: мат. междун. научн.-практ. конф. ГНУ ВНИИ виноградарства и виноделия им. Я.И. Потапенко Россельхозакадемии. Новочеркасск: Изд-во ГНУ ВНИИВиВ им. Я.И. Потапенко, 2008. C.10-13.

24. Лазаревский М.А. Изучение сортов винограда. Ростов-на-Дону: Изд-во Ростовского ун-та, 1963. $151 \mathrm{c.}$

25. Амирджанов А.Г., Сулейманов Д.С. Оценка продуктивности сортов винограда и виноградников: Методические указания. Баку, 1986. 54 с.

26. Сборник технологических инструкций, правил и нормативных материалов по винодельческой промышленности / под ред. Г.Г. Валуйко. М.: Агропромиздат, 1985. $511 \mathrm{c}$.

27. ГОСТ 31782-2012 Виноград свежий машинной и ручной уборки для промышленной переработки. М.: Стандартинформ, 2014.

\section{References}

1. Polulyah A.A., Volynkin V.A., Lihovskoj V.V. Geneticheskie resursy vinograda instituta «Magarach». Problemy i perspektivy sohraneniya // Vavilovskij zhurnal genetiki i selekcii. 2017. T. 21. № 6. S. 608-616. DOI: 10.18699/VJ17.276

2. Marrano A., Grzeskowiak L., Moreno Sanz P., Lorenzi S. et al. Genetic diversity and relationships in the grapevine germplasm collection from Central Asia // Vitis - Journal of Grapevine Research. Vol. 54 (Special Issue): January 2015: P. 233-237.

3. Alba V., Bergamini C., Genghi R. et al. Ampelometric Leaf Trait and SSR Loci Selection for a Multivariate Statistical Approach in Vitis vinifera L. Biodiversity Management // Molecular Biotechnology. 2015; 57: 709. [Elektronnyj resurs]. URL: https://doi.org/10.1007/s12033-015-9862-5 (data obrashcheniya 15.06.2019)

4. Failla O. East -West collaboration for grapevine diversity exploration and mobilization of adaptive traits for breeding: A four years story // Vitis - Journal of Grapevine Research. 2015; 54: 1-4.

5. Maletić E., Pejić I., Karoglan Kontić J. et al. Ampelographic and genetic characterization of Croatian grapevine varieties // Vitis - Journal of Grapevine Research 2015; 54 (Special Issue): 93-98.

6. Petrov V.S., Aleinikova G.Yu., Naumova L.G., Lukyanova A.A. Adaptive reaction of grape varieties in conditions of climate change // Lozarstvo i vinarstvo. 2018; 6: 18-31.

7. Zoghlami N., Riahi L., Laucou V. et al. Genetic structure of endangered wild grapevine Vitis vinifera ssp. sylvestris populations from Tunisia: Implications for conservation and management // Forest Ecology and Management. 2013; 310: 896-902. DOI 10.1016/j.foreco.2013.09.039

8. Anapskaya ampelograficheskaya kollekciya - krupnejshij centr akkumulyacii i izucheniya genofonda vinograda v Rossii / M.I. Pankin, V.S. Petrov, A.A. Luk'yanov i dr. // Vavilovskij zhurnal genetiki i selekcii. 2018. № 1 (22). S. 54-59. DOI: 10.18699/VJ18.331

9. Maghradze D., Maletic E., Maul E., Faltus M., Failla O. Field genebank standards for rapevines // Vitis. 2015; 54:273-279.

10. Novikova L.Yu., Naumova L.G. Strukturirovanie ampelograficheskoj kollekcii po fenotipicheskim harakteristikam i sravnenie reakcii sortov vinograda na izmeneniya klimata // Vavilovskij zhurnal genetiki i selekcii. 2019. T. 23 № 6. S. 142-149. DOI:10.18699/VJ19.551 
11. Goryslavets S, Risovannaya V, Memetova E. et al. Genetic diversity of ancient grape cultivars of the Crimea region // Vitis - Journal of Grapevine Research. 2015; 54(1):37-41.

12. Pelengic R., Koruza B. Slovenia grapevine germplasm // Acta Agriculturae Slovenica. 2012; 99(3):429-432.

13. Li S.H., Archbold D., London J. Collection, conservation, evaluation and utilization of Vitis amurensis germplasm resources in China // Acta Horticulturae. 2015; 1082:79-86. DOI: 10.17660/ActaHortic.2015.1082.10

14. Maul E., Töpfer R., Carka F. et al. Identification and characterization of grapevine genetic resources maintained in Eastern European Collec-tions // Vitis. 2015; 54:5-12.

15. Harakteristika nekotoryh aborigennyh dagestanskih sortov vinograda metodom SSR-analiza i po osnovnym ampelograficheskim priznakam list'ev / E.T. Il'nickaya, I.I. Suprun, L.G. Naumova i dr. // Vavilovskij zhurnal genetiki i selekcii. 2017. T. 21. № 6. S. 617-622. DOI: 10.18699/VJ17.277.

16. Izuchenie geneticheskogo skhodstva donskih aborigennyh sortov vinograda s primeneniem SSR-analiza i po osnovnym ampelografiche-skim priznakam lista / E.T. Il'nickaya, S.V. Tokmakov, I.I. Suprun i dr. // Sel'skohozyajstvennaya biologiya. 2016. T. 51. № 1. S. 60-67. DOI: 10.15389/agrobiology.2016.1.60rus

17. Donskie aborigennye sorta vinograda. 2-e izd. pererab. i dop. / A.M. Aliev, L.V. Kravchenko, L.G. Naumova i dr. Novocherkassk: Izd-vo VNIIViV im. Ya.I. Potapenko Rossel'hozakademii, 2013. $132 \mathrm{s.}$

18. Troshin L.P. Ampelografiya i selekciya vinograda. Krasnodar: Vol'nye mastera, 1999. $138 \mathrm{~s}$.

19. Il'nickaya E.T., Tokmakov S.V. Izuchenie polimorfizma SSR-lokusov yuzhnorossijskih aborigennyh sortov vinograda [Elektronnyj resurs] // Plodovodstvo i vinogradarstvo Yuga Rossii. 2014. № 27(3). S. 1-6. URL: http://journalkubansad.ru/pdf/14/03/01.pdf. (data obrashcheniya: 02.05.2020).

20. Panahov T., Salimov V., Nadzhafov D. Malorasprostranennye cennye sorta vinograda Nahichevani // Vinodelie i vinogradarstvo. 2011. № 5. S.38-39.

21. Uchastie gruzinskih sortov v selekcii vinograda / T. Vahtangadze, D. Magradze, R. Chipashvili i dr. // Interaktivnaya ampelografiya i selekciya vinograda: mater. mezhdun. simpoz. Krasnodar, 2012. S. 7.

22. Salimov V.S. Sbor, sohranenie i perspektivy prodolzhitel'nogo ispol'zovaniya geneticheskih resursov vinograda // Interaktivnaya ampelografiya i selekciya vinograda: mater. mezhdun. simpoz. Krasnodar, 2012. S. 197-198.

23. Adzhiev A.M., Musaev I.A., Karaev M.K. Aborigennye sorta vinograda Dagestana kak genofond dlya selekcii novyh sortov // Mobilizaciya i sohranenie geneticheskih resursov vinograda, sovershenstvovanie metodov selekcionnogo processa: mat. mezhdun. nauchn.prakt. konf. GNU VNII vinogradarstva i vinodeliya im. Ya.I. Potapenko Rossel'hozakademii. Novocherkassk: Izd-vo GNU VNIIViV im. Ya.I. Potapenko, 2008. S.10-13.

24. Lazarevskij M.A. Izuchenie sortov vinograda. Rostov-na-Donu: Izd-vo Rostovskogo un-ta, 1963. $151 \mathrm{~s}$.

25. Amirdzhanov A.G., Sulejmanov D.S. Ocenka produktivnosti sortov vinograda i vinogradnikov: Metodicheskie ukazaniya. Baku, 1986. $54 \mathrm{~s}$.

26. Sbornik tekhnologicheskih instrukcij, pravil i normativnyh materialov po vinodel'cheskoj promyshlennosti / pod red. G.G. Va-lujko. M.: Agropromizdat, 1985. $511 \mathrm{~s}$.

27. GOST 31782-2012 Vinograd svezhij mashinnoj i ruchnoj uborki dlya promyshlennoj pererabotki. M.: Standartinform, 2014. 